\title{
Central Banking in Modern Democracies: Private vs. Public Control
}

\author{
PANAGIOTIS KOTSIOS \\ Hellenic Open University, Greece*
}

\begin{abstract}
Central banks are among the most powerful institutions in the world: they are granted a legal monopoly in the issuance of money, set interest rates, monitor the banking sector and generally control a country's money supply and monetary policy. Their decisions and actions affect directly or indirectly almost every economic activity on the planet. However, most of these institutions decide and act independently from government, they are managed by appointed rather than democratically-elected officials and these officials usually come from the private banking sector. These facts generate questions about the functionality of the system and its efficiency in managing global finance. The goal of this research is to investigate the status of central bank management and ownership across the world today, and examine both philosophically and ethically the arguments for and against central bank independence in modern democracies. The analysis concludes that modern democracies should reassess the structure of central banking and address methods and practices that could possibly jeopardize economic development and the effective functioning of democracy in the long run.
\end{abstract}

Keywords: central banks, ownership, governance, independence, democracy

JEL Classifications: E59

\section{Introduction}

The goal of this research is to investigate the status of central bank management and ownership across the world today and examine both philosophically and ethically the arguments for and against central bank independence in modern democracies. The research starts with a short literature review about the history of central banks, their goals and functions, ownership status, independence from government, accountability and transparency rules. Next is an outline of the methodology that is applied in the research. The analysis part includes the results of the primary research and critical analyses of central banks' ownership structure and independence. In the last part of the study there is a summary of the conclusions.

\footnotetext{
*panagiotiskotsios@gmail.com
}

(C) 2019 Panagiotis Kotsios. Licensed under the Creative Commons Attribution - Noncommercial 3.0 Licence (http://creativecommons.org/licenses/by-nc/3.0/. Available at http: //rofea.org. 
Review of Economic Analysis 11 (2019) 233-254

\section{Literature Review}

\subsection{History of Central Banks}

The history of central banking goes back to the $17^{\text {th }}$ century, to the founding of the Swedish Riksbank. The Riksbank was established in 1668 as a joint stock bank in order to lend government funds and to act as a clearing house for commerce (Moenjak, 2014). A few decades later, in 1694, the most famous central bank of the era, the Bank of England, was founded also as a joint stock company to purchase government debt. Some authors argue that the modern-day notion of central banking should be dated from the 1844 Act, when the Bank of England received a monopoly on the issue of banknotes (e.g. Davies and Green, 2010). Other central banks were set up later in Europe for similar purposes. For example, the Banque de France was established in 1800 by Napoleon to stabilize the currency after the French Revolution and to aid in government finance. The other main European central banks took on these responsibilities in the last decades of the $19^{\text {th }}$ century. An analytical outline of central banking institutions before 1900 can be found in Capie et al (1994). The number of central banks increased rapidly in the $20^{\text {th }}$ century, with the establishment of 143 new institutions between 1900 and 1990 (Pringle and Mahate, 1993). The U.S. had two central banks in the early nineteenth century, the $1^{\text {st }}(1791-1811)$ and $2^{\text {nd }}(1816$ to 1836$)$ Bank of the United States. Both were set up on the model of the Bank of England, but their charters were not renewed due to concerns about concentration of power (Bordo, 2017). The Federal Reserve System was created much later, in 1913, and it belongs to a later wave of central banks, which emerged at the turn of the $20^{\text {th }}$ century with the goal of providing financial stability. Today there are more than 180 central banks or monetary authorities around the world.

\subsection{Aims of Central Banks}

Central banks were initially created in order to issue currency and provide banking services to governments. While these early central banks helped fund government debt, they were also engaged in banking activities. Since they held the deposits of other banks, they came to serve as "banks for bankers", facilitating transactions between them. Because of their large reserves they also became the lender of last resort in periods of financial crises (Bordo, 2017). Their aims also involved currency management and the holding of gold reserves. After World War II, their objectives were extended to include high levels of employment and growth (Capie et al, 1994).

In a recent study, carried out in 2006, researchers Friseld, Roszbach and Spagnolo from the Swedish Riksbank asked forty-seven central banks how they perceived their objectives. Around half responded that price stability was their primary objective (46\%). Other objectives included preserving the value of the currency (13\%), providing efficient payment mechanisms $(6 \%)$, preserving the purchasing power of domestic currency (4\%), guiding banking 


\section{KOTSIOS Central Banking in Modern Democracies}

operations (2\%), monetary stability (2\%) and other more complex objectives $(27 \%)$. It must be mentioned that many central banks have high employment and economic growth as basic targets set by law. The specific set of goals that each central bank is trying to achieve is defined by national legislation and this has been named the target variable. The means that central banks use in order to achieve these targets have been named the instrument variable (Davies and Green, 2010). The main instruments that a central bank can use to achieve its goals are the following (McDonell and Brue, 2008; Mankiw, 2009): Open-market operations, meaning the buying and selling of government bonds, the reserve ratio, meaning the portion of depositors' balances that commercial banks must have on hand as cash and the discount rate, meaning the interest rate that the central bank charges to commercial banks.

\subsection{Functions of Central Banks}

Economists and central bankers have tried to come up with a satisfactory list of central banking functions. De Kock (1974) mentions that the 10 main functions of central banks are: 1. Monopoly of note issue; 2. Banker and adviser to the government; 3. Act as the custodian of cash reserves of commercial banks; 4. Act as a lender of the last resort; 5. Control the credit of the country; 6. Maintenance and management of foreign exchange rate; 7.Clearing house facilities; 8. Publication of statistical data and other useful information; 9. Keep and manage foreign exchange reserves of the country; 10.Control fluctuations in order to curb inflation. In 1983, an IMF paper authored by Collyns, offered a list of the functions of a central bank, categorizing them in 5 areas: 1. currency issue and foreign exchange reserve management; 2. banker to the government; 3. banker to commercial banks; 4. regulation of the financial system; and 5. monetary and credit policy.

In a more recent attempt, Singleton (2011) listed the following 10 basic central bank functions: 1. Issuing legal tender banknotes and coinage; 2. Implementing and formulating monetary policy; 3. Providing banking and agency services for the government, and often manage the public debt; 4. Keeping cash reserves of commercial banks and assisting in the settlement of clearance balances between them; 5. Supervising and regulating the financial system, and in some circumstances acting as a lender of last resort; 6. Applying government policy on the exchange rate and keeping the national reserves of international currency; 7. Promoting economic development; 8. Advising governments on economic policy; 9. Participating in cooperative international monetary arrangements; 10. Other functions such as the provision of banking services to the public, consumer protection or the part ownership of a stock exchange. The functions of course may vary both between countries and within the same country over time. What is clear, in any case, is that central banks are very powerful institutions and that their role is of enormous importance in most economies and countries around the world today. 


\section{$2.4 \quad$ Ownership}

Regarding the issue of ownership, one would imagine that all central banks across the world are state owned institutions. However this is not always the case. Many central banks, especially the oldest ones, like the Bank of England, began as private sector companies; others started as public-sector agencies, like the Federal Reserve Board. The great majority are now state owned, though partial private ownership persists in a few cases. A research by the Bank of International Settlements (BIS) in 2009 in a sample of 47 central banks, concluded that $77 \%$ were fully owned by the state or the public sector, $11 \%$ were majority or half owned by state or public sector, $4 \%$ were majority owned by the private sector and $1 \%$ had some other mixed ownership form. As examples of central banks with private ownership, the BIS research mentions:

- Belgium, South Africa and Turkey, where part or all of the shares of the central bank's capital are publicly listed and available for purchase by private individuals,

- the US Federal Reserve System and the Swiss National Bank, which have a mixed public/private ownership structure that is specified by law, ${ }^{1}$

- Belgium, Greece and Italy which have central banks partly or wholly owned by private sector shareholders.

The development of the ownership structures of central banks is also recorded in the book by De Kock (1974). More recently Rossouw (2014) noted that on 2004 central banks with shareholders were to be found in Austria, Belgium, Greece, Italy, Japan, South Africa, Switzerland and Turkey, while the 12 Federal Reserve Banks in United States also have shareholders. However the central bank of Austria was nationalised in 2010, leaving the remaining as central banks with private shareholders.

\subsection{Independence}

A very contentious aspect of central banking that has appeared along with the development of central banks is central bank independence from government. Central bank independence (CBI) refers to the freedom of central bankers from direct political or governmental influence in the conduct of policy (Walsh, 2005). CBI is considered to have two key dimensions: "political independence" meaning independence from political influence in defining its policy objectives, and "economic independence", meaning independence in the choice of policies in pursuit of monetary policy goals (Grilli et al, 1991). Debelle and Fischer (1994) named these two aspects "goal independence" and "instrument independence". Goal independence refers

\footnotetext{
${ }^{1}$ The Swiss National Bank is a company subject to the law governing joint stock companies, but its officials are subject to legislation that governs the behaviour of federal authorities (BIS, 2009, p.64).The Swiss Bank's shares are traded on the Swiss stock exchange.
} 


\section{KOTSIOS Central Banking in Modern Democracies}

to a central bank's ability to determine policy goals without the direct influence of a fiscal authority, while instrument independence refers to the central bank's ability to freely adjust its policy tools in pursuit of monetary policy goals. The BIS (2009) determines the degree of a central bank's autonomy by 4 elements: 1 . Clear and non-contradictory mandates; 2. Limited relationship to the state and no obligation to finance government activities; 3. Power to make policy decisions; 4. Appointment process and the term limits for its officers can be made by the state, but afterwards officials must be insulated from political influence.

It is astonishing, however, that in all the relevant literature there is only one main theoretical argument in favour of central bank independence: political interference on monetary policy and the time-inconsistency problem. For example authors like Lastra (2006); Abel et al (2008); McConnell and Brue (2008) mention that independent central banks can be insulated from political pressures to pursue overly expansionary policies. In order to get reelected or satisfy the general public, politicians may be tempted to increase spending and create inflation in the long run. It is claimed that a politically insulated central bank is more likely to be concerned with long-run objectives and be a better defender of price stability. Another argument found on the literature is related with the possible discipline that independent central banks may exert on fiscal policies and budget deficits. Various authors have tested this relationship and some found no relationship (e.g. Sikken \& Haan, 1998), while others found a negative one (e.g. Masciandaro \& Tabellini, 1988; Bodea, 2013; Burdekin \& Laney, 2016).

The counterargument to central bank independence is that this practice is inconsistent with democratic principles. Having monetary policy controlled by an elite group of policy makers that are insulated from elected politicians can be undemocratic and risky for the general public (Mishkin, 2012; Cecchetti and Schoenholtz, 2015; Wood, 2015). Other arguments arise from independent central bank failures, like the period of Great Inflation in the U.S. and the recent financial crisis. All these arguments will be analysed in more detail later on this article.

Today the reality is that many central banks around the world are, legally at least, independent from government. An example is the European Central Bank (ECB), which mentions in its website: "Neither the ECB nor the national central banks (NCBs), nor any member of their decision-making bodies, are allowed to seek or take instructions from EU institutions or bodies, from any government of an EU Member State or from any other body". Granting central bank independence is also a prerequisite for membership in the Eurosystem. Other examples include the Bank of England that gained operational independence with a Labour Act on 1997, the Bank of Japan on 1998, while the Fed has enjoyed a high degree of insulation from political interference since 1951.

Empirical research has been carried out in relation to CBI and its effect on monetary policy. The most widely employed index of central bank independence is due to Cukierman, Webb, and Neyapti (1992), although alternative measures were developed by Bade and 
Parkin (1978), Grilli, Masciandaro, and Tabellini (1991), Dinchen \& Eichengreen (2014) and others. Several authors including Alesina (1988); Grilli, Masciandaro, and Tabellini (1991); Cukierman et al (1992); Jonsson, (1995) and Eijffinger et al (1998) found that more independent central banks were associated with lower levels of inflation. Alesina and Summers (1993) however could not find any correlation between CBI and real economic performance. However, the empirical work attributing low inflation to central bank independence has been criticized on the basis that these researches may fail to measure other factors that affect inflation. For example Campillo and Miron (1997) found little role for central bank independence, after controlling for other potential determinants of inflation. Moreover, by comparing the implementation dates of CBI reforms with long-term inflation trends for 29 OECD countries, Daunfeldt and de Luna (2008) found that price stability had been achieved in most countries before their central banks became more independent.

\subsection{Transparency}

The method that modern democracies have used in order to control the vast amount of power that they have granted to independent central banks is through accountability and transparency rules. Kaltenthaler et al (2010) refer to central bank accountability as the ability of the governed to know the reasoning behind policy decisions, reward or punish policymakers and have the power to remove them when their decisions don't reflect citizens' preferences for policy outcomes. Transparency is also a very important element of accountability (Eijffinger and Hoeberichts, 2002). Whatever arrangements concerning democratic accountability may exist, their scope is limited without transparency and the availability of information about a central bank's decisions and policies. Siklos (2012) in his book explains the importance of communication for creating trust to the general public for the central bank's actions and decisions. A good example is the Reserve Bank of New Zealand (RBNZ), which in 1990 became the first central bank to adopt inflation targeting as a monetary policy regime, while putting great emphasis on transparency and accountability (Moejnak, 2014). There are public announcements of inflation targets and the reasoning behind changes in the interest rate, and accountability is conveyed through the fact that if the inflation target is missed without a good explanation, the RBNZ governor can be removed. This emphasis on transparency and accountability helped enhance the RBNZ's credibility in its conduct of monetary policy. On the contrary, the European Central Bank (ECB) is considered to be one of the most independent central banks in the world (Arnone et al, 2007), and also one of the less transparent in comparison with other central banks (Davies and Green, 2010). Legal accountability of the G7 central banks have been compared in a research 


\section{KOTSIOS Central Banking in Modern Democracies}

by Eijffinger and De Haan (1996) and large differences have been observed from country to country.

\subsection{Goals of the Research}

Keeping in mind the long history of central banking, the very important role of monetary policy, the vast amount of power that central banks are controlling today and the extensive literature on the topic, there is a number of important questions that arise: Should central banks be privately or state owned? Should they operate independently from democratically elected governments? Is that the optimal way to provide financial and monetary stability and economic growth? Are transparency and accountability the methods for ensuring that a central bank's decisions will coincide with the will of the general public?

\section{Methodology}

In order to answer these questions this research will apply a methodology which consists of three parts. Firstly, in order to collect updated information about the topics of central bank ownership and independence, the authors have contacted electronically, through e-mail, the 76 central banks of the countries that are considered democratic according to the Economist Intelligence Unit's (EIU) Democracy Index 2016. The Democracy Index intends to measure the state of democracy in 167 countries, of which 166 are sovereign states and 165 are UN member states. In addition to a numeric score and a ranking, the index categorises countries in one of four regime types: full democracies, flawed democracies, hybrid regimes and authoritarian regimes. Full democracies refers to countries with free and fair elections, political freedom, civil liberties, satisfactory functioning of government, independent media and independent judiciary system, while Flawed democracies are countries that share the above characteristics, but have significant weaknesses in other aspects of democracy, including problems in governance, an underdeveloped political culture and low levels of political participation. The number of full democracies for 2016 was 19 and of flawed democracies 57. The questions that were sent to central banks were 6 in total, and they regarded three topics - Ownership, Management and Independence. The exact questions were the following:

\section{A. Ownership}

1. Is the central bank in your country a state organization, a private company or a mixed ownership company (shares belonging to both the state and private shareholders)?

2. In case it is a private or a mixed ownership company, are the shareholders published? 
B. Management

3. How is the central bank's governing board selected?

4. Are they elected (from national elections) or appointed officials?

C. Independence

5. Is the central bank independent from government by law?

6. If yes, how is transparency for the central bank's decisions secured for the general public?

The questions were short in order to try to increase the response rate, since it is very usual to have low response rates in central banks researches (Blinder et al, 2017). The emails were sent during the summer of 2017, from the $30^{\text {th }}$ of July until the $1^{\text {st }}$ of August and answers were expected until the $20^{\text {th }}$ of August. A reminder in all central banks was sent on the $5^{\text {th }}$ of August.

Secondly, there is going to be a critical analysis of central bank ownership structure, based on the collected information, and thirdly there is going to be a critical analysis of the various arguments that have been put forward in favour and against central bank independence. The three parts of the analysis will hopefully provide some useful conclusions in the end.

\section{Results and Discussion}

\subsection{Questionnaire Replies}

The response rate to the questionnaires was low, as only 17 central banks from the 76 democratic countries replied. The sample was complemented with 2 central banks that the required information was easily accessible from their website, the Bank of Greece and the Federal Reserve, creating a total sample of 19 out of 76 central banks ( $25 \%$ response rate).

A record of the received replies is presented in Appendix 1. From the central banks that replied $14(73 \%)$, replied that they are state owned, and in $5(27 \%)$ private individuals and organizations had whole or some share of the central bank's capital. The central banks with private shareholders are listed in Table 1. Of these 5 central banks, the shareholders were directly or indirectly publicized in 4 of them, and only in the case of Greece the exact shareholders and their shares of capital are not officially publicized. Regarding the other questions, all of the 19 central banks (100\%) answered that they are governed by appointed, non-elected (from general elections) officials. Also, all declared that they are independent from their government. Appendix 1 presents the central bank's replies along with their score in the Dincer-Eichengreen (2014) independence index for 2010, whenever available. All banks have declared to use various effective transparency policies, including: reports, 


\section{KOTSIOS Central Banking in Modern Democracies}

publications, parliament auditions, press releases, speeches, conferences, seminars, statistical databases, multimedia content, website, contact facility etc. Additionally the Reserve Bank of Australia every year consults with the government in order to set targets.

Table 1: Central banks in the sample with private shareholders

\begin{tabular}{|c|c|c|c|c|}
\hline No & Country & Central Bank & Ownership & Shareholders \\
\hline 1 & Switzerland & $\begin{array}{l}\text { Swiss National } \\
\text { Bank }\end{array}$ & $\begin{array}{l}\text { Cantons and cantonal banks (52\%) } \\
\text { and private individuals ( } 48 \%)\end{array}$ & Publicized \\
\hline 2 & Japan & Bank of Japan & $\begin{array}{l}55 \% \text { state and } 45 \% \text { private } \\
\text { individuals }\end{array}$ & Publicized \\
\hline 3 & $\begin{array}{l}\text { United } \\
\text { States }\end{array}$ & $\begin{array}{l}\text { Federal Reserve } \\
\text { System }\end{array}$ & $\begin{array}{l}\text { Owned by commercial banks but } \\
\text { profits over } 6 \% \text { are paid to the } \\
\text { Treasury }\end{array}$ & Publicized \\
\hline 4 & Italy & Banca d' Italia & $\begin{array}{l}\text { Shares belong to a) Italian banks b) } \\
\text { Italian insurance companies c) Italian } \\
\text { foundations d) Italian social security, } \\
\text { insurance bodies and pension funds. } \\
\text { No shareholder may hold, directly or } \\
\text { indirectly, a share of the capital } \\
\text { greater than } 3 \%\end{array}$ & Publicized \\
\hline 5 & Greece & Bank of Greece & $\begin{array}{l}\text { State } 8,93 \% \text {, State organizations, } \\
\text { Social insurance funds, private } \\
\text { individuals } 91,07 \%^{1}\end{array}$ & $\begin{array}{l}\text { Not directly } \\
\text { publicized }\end{array}$ \\
\hline
\end{tabular}

Note: The Bank of Greece released an announcement on 29/5/2012 that claimed that the Greek State indirectly controls about $70 \%$ of capital. Shareholders with share capital over $2 \%$, apart from the Greek state, have no voting rights during general assemblies.

\subsection{Critical Analysis of Ownership Structure}

Most countries around the world have state owned central banks, with very few exceptions. What are the reasons for having a privately owned central bank? Are there any advantages or there is clear conflict with private ownership and the very important role that these institutions play for the general public? A basic argument in favour of private central bank ownership is that it is insulated from state control and political interference. According to the prevailing central bank theory, these may undermine the central bank's ability to effectively choose and implement monetary policy. Perhaps also, private ownership structure assists in avoiding the complex and time consuming bureaucratic procedures that are required for state agencies, thus creating time savings and more flexible management structures. Moreover, the 
BIS (2009) mentions that in cases of private ownership, all important policymaking powers are shielded from private shareholder influence and shareholders rarely have a say over financial arrangements, since financial and policy objectives can conflict. Roussow (2015) mentions that although private shareholders have no say over decisions about monetary policy, central banks report on these decisions to their shareholders, and this can be considered as an extra layer of control, that enhances governance, accountability and transparency. Furthermore, shareholding by commercial banks (as in the US and Italy) can provide an opportunity to assist commercial banks in financial distress, as was the case in Italy with the revaluation of the central bank in 2014. Finally, as mentioned again by the BIS (2009), all in all, different ownership models do not appear to affect the performance of the main tasks of the central bank and are instead "mostly arrangements designed to satisfy local constitutional or practical needs" (p.65).

On the other hand, as mentioned by Davies and Green (2010), central banks are clearly carrying out public objectives, so the case for private ownership is weak. Private shareholding can entail risks, as shareholders may challenge a central bank's actions. Moreover, where the shares are quoted, there can be inconsistency between stock exchange reporting requirements and policy-driven restrictions on disclosure. The BIS (2009) mentions, as a negative side, that publicly listed shares can consume a significant amount of the central bank's time and resources. In cases where the shareholders are not publicized, this can create distrust about the central bank's ownership and goals. As mentioned by Roussow (2015), the Bank of Italy and the 12 US Federal Reserve Banks allow ownership to private banks. In this case there may be a supervisor-to-supervisee relationship, and there may be in some cases conflict between the interests of the general public and the actions of the shareholding private banks.

Roussow (2014) also claims that central banks with private ownership are to a certain extent a relic of the past, given that this system of ownership was not adopted (with the exception of Pakistan) for central banks established after the $2^{\text {nd }}$ World War. However the Central Bank of Pakistan was nationalised in 1975, while the most recent nationalisation was that of the central bank of Austria in 2010. Consequently there is a very small number of privately owned central banks left in the world, and in these countries the central bank's ownership status should probably be a topic of public debate.

\subsection{Critical Analysis of Central Bank Independence}

Another important issue that should also be a matter of public debate is related with central bank independence. The largest economies of the world have granted some small or large degree of independence in central bankers. The main arguments that have been put forth in favour of central bank independence are the following: 


\section{KOTSIOS Central Banking in Modern Democracies}

A) Political Interference: As mentioned earlier, in all the extensive literature about central banking, surprisingly there is only one theoretical argument in favour of central bank independence: the possible negative consequences that irresponsible political interference can have on the money supply and inflation levels. If politicians choose to increase government spending in order to satisfy voters and get re-elected in the short run, this can have very negative effects on the price level in the long run. As explained better by Fischer (2015), the traditional economic case for CBI rests on countering inflationary biases that may occur in the absence of an independent central bank. One reason for such a bias is political pressure to boost output in the short run for electoral reasons. Another reason is the incentive for politicians to use the central bank's power to issue money as a means to finance government spending. Another reason is related with the time-inconsistency problem of monetary policy making, which can undermine the central bank's credibility in keeping inflation low and create higher inflation expectations in the general public. By delegating monetary policy to an independent and conservative (i.e. inflation averse) central bank, promises to keep inflation low become more credible (Bernanke, 2010).

The significance of central bank independence arises also from the different priorities between politicians and central bankers. Politicians are aware of the importance of price stability, but they tend to be less willing to sacrifice other goals, such as growth and employment, to the fight against inflation (Goodman, 1991). Central bankers tend to be more concerned with the risks of inflation for a variety of factors, of which the most significant appears to be the close ties between central banks and the financial community. Banks are highly averse to both unexpected inflation and market instability, as their long-term interests depend upon the central bank's ability to control inflation. Moreover, Maxfield (1997) suggested that in some cases CBI reforms have been implemented, especially in less developed countries, to signal creditworthiness to foreign investors.

B) Empirical Research: The belief about the negative relation of CBI with inflation levels is supported by empirical research. Much of it appeared in the 1980s in papers by Bade and Parkin (1984), Alesina (1988, 1989), Alesina and Summers (1993), Grilli et al (1991) and Alesina and Gatti (1995). By the late 1990s, the opinion that central bank independence improves monetary policy outcomes was also widespread in academic textbooks (Howells and Mariscal, 2006). Examples of more recent studies of the topic with similar results are those by Crowe and Meade (2008) and Anastasiou (2009).

C) Transparency and Accountability: Concerns about the power issued to independent central banks and the effectiveness of their decisions have been addressed by various accountability and transparency mechanisms. As highlighted by Fisher (2016), a central bank's accountability is enforced by regular reporting on monetary policy actions and outcomes to the legislature, to the government and to the public. Accountability of the central 
bank helps deal with the potential conflict between independence and the fact that unelected officials are determining policies critical to a country's economy. Eijffinger and Hoeberichts (2002) also stress the importance of transparency as a very important element of central bank accountability. They support that when the reasons for a certain monetary policy decision lay open, it is easier to make a judgement and to hold central bank officials accountable for their behaviour. So, a central bank should be required to report at regular intervals on its past performance and future plans for monetary policy in accordance with the monetary objectives. The authors also describe a variety of transparency procedures that are applied in various countries around the world, including central banks' meetings minutes, reports, forecasts and audits. In addition, Howells and Mariscal (2006) mention several reasons why monetary policy might be improved by transparency. Firstly, transparency makes monetary policy more predictable in the short and medium run. Predictability contributes to market stability since it improves public understanding of the rules that govern central bank decision making and reduces uncertainty. Secondly, greater disclosure of the policy making process ensures that market expectations by the private sector can be formed more accurately and efficiently (Blinder et al, 2001).

In contrast to the arguments mentioned in favour of CBI, there are many arguments that question and challenge the notion of central bank independence. Some of them are mentioned in the following paragraphs.

A) Democratic Control: A main argument has to do with the democratic limits of independence for an institution that plays such an important role in every economy. If we accept that democracy is the best type of political system, and in a democracy everything should be controlled by the general public (or their elected officials in representative democracies), then monetary policy is just too important to be left in the hands of unelected individuals, that are able to exercise it as they like, and without any legal repercussions. This practice is clearly beyond democratic limits and raises questions about its purposefulness and effectiveness.

Advocates of central bank independence also claim that independence is necessary to protect the economy from short-term political interference to increase the money supply, which can affect the price level in the long-run. Politicians are supposedly short sighted and don't see the negative long term negative economic effects. Somebody could easily say that this argument actually has no logical basis. Politicians in reality make much tougher longterm decisions, they are very well informed about the time consistency problem and are more than capable to comprehend the negative effects of inflation. The difference is that in wellfunctioning democracies they do everything with the authorization and control of the public. If they make the wrong decisions, they can be hold accountable by law and the general public 


\section{KOTSIOS Central Banking in Modern Democracies}

in the following elections. In reality, all political decisions have long term effects, and there is no obvious reason why the time consistency argument is valid only for monetary purposes.

Blinder (1998) believes it's a mystery why governments have chosen the delegate such powers in independent central banks, and have not done so for example in tax policy. Moreover, often we meet independent authorities operating within states, but their operation is strictly defined by government laws, their effectiveness is regularly audited by the government and the general public, and of course there are legal repercussions when they surpass the legal framework under which they are supposed to operate. On the contrary central banks are in pursuit of, and have in some cases achieved, a much higher degree of autonomy. Friedman (1962, p. 228-229), while questioning the best arrangement for monetary policy, he mentions another three possible defects of independent central banks: a) dispersal of responsibility, which promotes shirking responsibility in times of uncertainty and difficulty, b) they are highly dependent on the personalities of central bankers and c) an independent central banks inevitably give undue emphasis to the point of view of bankers, especially regarding the credit market.

B) Not Real Independence: Others might say that in reality most central banks only claim to be independent. They have been founded by laws voted by the government, they are responsible for the government's banking activities, their governors are appointed by the government, their goals and tools are determined by the government, they are audited by the government and the government has the ability to change their legal charter whenever it seems fit. Also as correctly noted by Wray (2014), if a government decides to spend beyond budgeted amounts — perhaps in an attempt to replicate the experience of the Weimar Republic or Zimbabwe - the central bank would actually be powerless to prevent it. As Friedman (1962, p.227) puts it: Even when central banks have supposedly been fully independent, they have exercised their independence only so long as there has been no real conflict between them and the rest of the government". Ben Bernanke, former Chairman of the United States Federal Reserve, during a Congress hearing on 2012, said it clearly: "of course we'll do whatever Congress tells us to do". However these views are not shared by all central bankers. The ECB for example has a much different perception and degree of autonomy.

C) Role in the GFC: Other criticisms against CBI are related with independent central banks' failures. Leaving aside the long history of independent central bank mistakes, like the 1970's period of Great Inflation in the US, new criticisms against central bank independence have been put forward for their role in the recent Global Financial Crisis. It can be claimed that these institutions have a large portion of the blame for the outbreak of the financial crisis, since they are charged with the responsibility of securing financial stability. Steve Roach, former chief economist of Morgan Stanley, argued that the central banks bore the prime 
responsibility for the crisis (2007), mentioning that: "the art and science of central banking is in desperate need of a major overhaul-before it's too late".

Moreover, during the crisis central banks had to intervene at a grand scale to maintain financial stability. Blinder et al (2017) in an ECB report describe the actions that large central banks took in order to safeguard the stability of the financial system, "like lending to banks on a massive scale...or lending to nonbank financial institutions ...or purchasing non-traditional assets" (p.34) and stress the fact the these central banks have moved to the domain of fiscal policy. Fels (2016) also supports that many of the central banks' decisions that are required to address today's greatest problems have significant distributive consequences and are thus in the "realm of fiscal policy rather than monetary policy". Other critiques about the role of central banks in the GFC can be found on Buitter (2008). In conclusion, apart from being responsible for the tolerance that created the recent GFC, independent central banks are taking fiscal decisions about how taxpayers' money should be spend.

D) Bonds with the Banking Sector: Other criticisms come from the close relationship that central bankers have with private banks. Many central bankers used to work for the private banks that they later had to supervise, and this can create conflicts of interest. The role of bankers in effecting politics and central banking, even though obvious, remains to be discussed publicly. In his book about the role of private banks in central banking and politics, Adolph (2016, p.2) mentions : "Arguably, no sector of the economy is more responsible for the economic crisis that began in 2007, yet no other sector has emerged more profitably, or with greater leverage over policy in the United States and Europe".

E) Distrust: Perhaps the relationship of central banks with private banks and politicians is the reason there is large citizen distrust towards central banks. According to Eurobarometer survey of public opinion 2017, only 34\% of Europeans trust the European Central Bank (ECB), 17\% don't know it and 49\% declared that they distrust it. The results of Karthenahel et al (2010) also confirm the feelings of distrust towards the ECB. According to the authors many Europeans are concerned that their voice or that of their country is not being heard in the ECB's policy-making and this democratic deficit is damaging levels of support for the integration process as a whole. Distrust against central banks is common in other countries around the world also. In the US for example, a large portion of citizens, academics and politicians are questioning the Fed system's functionality, especially in the aftermath of the GFC.

F) Weaknesses of the Empirical Research: As mentioned earlier, central bank independence has been backed by empirical research that has claimed to prove the adverse relationship between CBI and inflation and was quickly accepted by academics and politicians. However this empirical research has been criticized for a number of reasons. Pollard (1993) summarizes the most important methodological weaknesses: 


\section{KOTSIOS Central Banking in Modern Democracies}

i) There is difficulty in measuring central bank independence. With few exceptions, most indexes apply equal weight to each factor and obviously a legal measure of independence may not reflect a bank's de facto level of independence. There also may be bias in the factors selected to measure independence. ${ }^{2}$

ii) In most studies political factors that affect inflation are not included in the calculations.

iii) Empirical use of these indexes may be problematic if $\mathrm{CBI}$ is an endogenous variable in the sense that countries with a commitment to price stability may have a greater propensity for independent central banks. If this is true, the establishment of an independent bank without a commitment to price stability will not bring inflation benefits. ${ }^{3}$

Moreover, Cukierman (1992) and Bouwman et al. (2005) point out that legal indicators of $\mathrm{CBI}$ are often incomplete and unreliable because laws do not explicitly specify the limits of authority between CBs and governments. Thus, the actual degree of CBI may not be well measured by legal independence indicators.

G) Accountability: Another source of criticism for central banks is related with the accountability mechanisms. If we consider as the central bank's ultimate goal to safeguard the public's interest, there should be appropriate responsibility mechanisms when this goal is not achieved. As noted by Davies and Green (2010), in the central bank context, accountability typically implies a duty to explain the reasons for decisions, after the event, and to answer questions on them. But rarely do any consequences, whether financial or otherwise, flow from these accounts. In most countries central bankers can be dismissed only for incapacity or gross misconduct and not for incompetence. Walsh (2002) also notes that granting long terms of office to central bankers limits the extent to which central bankers can be held accountable.

From all the arguments that were mentioned in favour and against CBI, it is clear that CBI is lacking a solid theoretical background, while the empirical research that supports has structural weaknesses. On the contrary there are well-based logical arguments and proofs in favour of the view that central banks should be directly controlled from democratically elected governments.

\section{Conclusions}

Through an analytical literature review, a primary research about the basic central bank characteristics in modern democracies and critical analyses of the central bank ownership and

\footnotetext{
${ }^{2}$ However it must be mentioned that Banaian et al (1998), used principal component analysis and found an insignificant and/or a positive rather than negative relationship of the 15 attributes of central bank independence that are included in the Cukierman index with mean inflation rates.

${ }^{3}$ Brumm (2011) tested the relationship between inflation and CBI and found that they are endogenously determined, while the negative correlation between the two remains robust.
} 
independence topics, this research has tried to shed light to the highly important topic of central banking. The author, as most individuals, agrees that central banks are necessary and their role in every modern economy is vital. But certain characteristics of modern central banks create suspicion and concern, especially in the aftermath of the recent financial crisis and the manner that it was confronted.

The first main research question was if central banks should be privately or state owned. From the primary research and the literature review on the topic it is concluded that most central banks around the world are state-owned. Keeping in mind the central role of these institutions for every economy, the impact of their decisions for the general public and the power they are granted, there is little space for private ownership and control. Private ownership is more likely to create suspicion and possible conflicts of interests rather than improve the central bank's performance. In the small number of countries with privately owned central banks, the ownership status should probably be a topic of public debate.

The second question asked if central banks should operate independently from democratically elected governments and if that is the optimal way to provide financial and monetary stability and economic growth. Even though the idea of independent central banks was quickly adopted by academic and political cycles, it is clearly lacking solid theoretical and empirical justification. As Howells and Mariscal (2006, p. 9) aptly put it: "The literature that has made central bank independence so fashionable presumes precisely this: that a legislative act ...carries more credibility than a promise by government to follow a low inflation policy".

The reality is that for the cost of hypothetical inflation, we are in risk of submitting a monopoly of money to a small number of unelected officials with close ties with the banking sector. The recent global financial crisis is an example of the cost that societies pay when they lack efficient control mechanisms for the financial sector. Monetary policy and financial regulation are clearly core government responsibilities and not targets that must be met by an independent central bank's governing board.

The third and final question is if central banking transparency and accountability are the methods for ensuring that a central bank's decisions will coincide with the will of the general public. From the literature review and the analysis of the arguments in favour and against central bank independence, it is clear that most central banks were not, are not, and perhaps should never be independent from governments. In modern democracies their role is just too important to be left in the hands of unelected officials. The various accountability and transparency policies that are applied are providing some level of democratic control and are certainly steps towards the right direction. However they cannot fully justify this vast transfer of responsibility from democratic governments to private individuals.

The main argument in favour of CBI, which is related with the time consistency problem, could be dealt with by an independent authority of experts that will continuously monitor the 


\section{KOTSIOS Central Banking in Modern Democracies}

government's monetary policy, and not the other way around. Alternatively, if there are independent central banks, they should operate, like any other national independent authority, in a very strict regulatory framework: clear legislation about its responsibilities, goal setting by the government, frequent reporting, strict accountability measures and increased transparency rules.

From the whole analysis it is clear that most modern democracies should reassess the notion and substance of central banking and address methods and practices that could possibly jeopardize economic development and the effective functioning of democracy in the long run. This research is of course limited by the low response rate and from the fact that it does not cover all the extensive literature about central banking. However it does point out some interesting directions for future research, including public opinions about central bank ownership and independence and the relation of CBI with real economic performance and social indicators.

\section{References}

Abel, A., Bernanke, B. and Croushore, D. (2008). Macroeconomics, 6th Edition, Pearson.

Adolph, V. (2016). Bankers, Bureaucrats, and Central Bank Politics, Cambridge Series in Comparative Politics.

Alesina, A. (1988). Macroeconomics and Politics, In Stanley Fischer (ed), NBER Macroeconomics Annual, Cambridge, Mass.: MIT Press. 17-52.

Alesina, A. (1989). Politics and Business Cycles in Industrial Democracies. Economic Policy 8, 58-98.

Alesina, A. and Summers, L. (1993). Central Bank Independence and Macroeconomic Performance: Some Comparative Evidence. Journal of Money, Credit, and Banking, 25(2), 151-162.

Alesina A. and Gatti R. (1995). Independent Central Banks: Low Inflation at No Cost?. American Economic Review, 1995, 85(2), 196-200.

Anastasiou, A. (2009). Central Bank Independence and Economic Performance. Cyprus Economic Policy Review, 3(1), 123-156.

Arnone, M., Laurens, B., Segalotto, J. and Sommer, M. (2007). Central Bank Autonomy: Lessons from Global Trends. IMF Working Paper, No. WP/ 07/88.

Bade, R. and Parkin, M. (1978). Central Bank Laws and Monetary Policies: A Preliminary Investigation, in M. Porter (ed.), The Australian Monetary System in the 1970s, Monash University.

Bade, R. and Parkin. M. (1984). Central Bank Laws and Monetary Policy. Department of Economics, University of Western Ontario, Canada.

Banaian, K., Burdenkin, R. and Willett, T. (1998). Reconsidering the principal components of central bank independence: The more the merrier?, Public Choice, 97, 1-12. 
Review of Economic Analysis 11 (2019) 233-254

Bank for International Settlements (2009). Issues in the Governance of Central Banks. Basel.

Bank of Greece (2012). Announcement about the regulatory framework of Bank of Greece operation, 29/05/2012, Retrieved 20-08-2017, from http://www.bankofgreece.gr/Pages/el/Bank/News/Announcements/DispItem.aspx?Item_I $\mathrm{D}=3966 \&$ List ID=1af869f3-57fb-4de6-b9ae-bdfd83c66c95\&Filter by=AN

Bernanke, B. (2010). Central Bank Independence, Transparency, and Accountability. Speech of Chairman Ben S. Bernanke at the Institute for Monetary and Economic Studies International Conference, Bank of Japan, Tokyo, Japan, May 25, 2010.

Bernanke, B. (2012). Statement on Committee on Financial Services, U.S. House of Representatives, July 18, 2012, Retrieved 12-07-2017, from http://www.youtube.com/watch?v=a7XV3vS1hAM

Blinder, A. (1998). Central Banking in Theory and Practice. Cambridge, MA: MIT Press.

Blinder, A, Goodhart, C., Hildebrand, P., Lipton, D. and Wyplosz, C. (2001). How do central banks talk?, International Centre for Monetary and Banking Studies, Geneva.

Blinder,A., Ehrmann, M., De Haan J. and Jansen D. (2017). Necessity as the mother of invention: Monetary policy after the crisis. Working Paper No 2047, ECB.

Bodea, C. (2013). Independent central banks, regime type, and fiscal performance: the case of post-communist countries, Public Choice, 155, 81-107.

Bordo, M. (2017). A Brief History of Central Banks, Federal Reserve Bank of Cleveland, Retrieved 12-07-2017, from https://www.clevelandfed.org

Bouwman, K., Jong-A-Pin, R. and De Haan, J. (2005). On the relationship between central bank independence and inflation: some more bad news. Applied Financial Economics Letters, 1, 381-385.

Brumm, H. (2011) Inflation and central bank independence: Two-way causality?, Economics Letters, 111, 220-222.

Burdekin, R. and Laney, L. (1988). Fiscal Policymaking and the Central Bank Institutional Constraint, Kyklos, 41, 647-662.

Burdekin, R. and Laney, L. (2016). Fiscal Policy making and the Central Bank Institutional Constraint Una Vez Más: New Latin American Evidence, Public Choice, 167(3-4), 277289.

Campillo, M. and Miron. J. (1997). Why Does Inflation Differ Across Countries? in C. D. Romer and D. H. Romer (eds), Reducing Inflation: Motivation and Strategy. Chicago: University of Chicago Press, 335-357.

Capie, F., Fischer, S., Goodhart, C. and Schnadt, N. (1994). The future of central banking: the tercentenary symposium of the Bank of England. Cambridge, UK : Cambridge University.

Cecchetti, S. and Schoenholtz, K. (2015). Money, Banking and Financial Markets, 4th Edition, McGraw Hill. 
KOTSIOS Central Banking in Modern Democracies

Collyns,C. (1983). Alternatives to the Central Bank in the Developing World. IMF, Occasional Paper No. 20.

Crowe, C. and Meade, E. (2008.). Central Bank Independence and Transparency: Evolution and Effectiveness, European Journal of Political Economy, 24(4), 763-777.

Cukierman, A. (1992). Central Bank Strategy, Credibility, and Independence: Theory and Evidence. Cambridge, MA: The MIT Press.

Cukierman, A., Webb S..and B. Neyapti, B. (1992). Measuring the Independence of Central Banks and Its Effects on Policy Outcomes. The World Bank Economic Review, 15(2), 353-398.

Daunfeldt, S.O., \& De Luna, X. (2008). Central bank independence and price stability: evidence from OECD countries. Oxford Economic Papers, 60(3), 410-422.

Daunfeldt S.O. \& Hellström J. \& Landström M. (2013). Why Do Politicians Implement Central Bank Independence Reforms?. Atlantic Economic Journal, 41(4),.427-438.

Davies, H. and Green, D. (2010). Banking on the Future: the fall and rise of central banking, Princeton University Press.

Debelle, G. and Fischer, S. (1994). How Independent Should a Central Bank Be?, In J. Fuhrer (ed), Goals, Guidelines and Constraints Facing Monetary Policymakers. Boston: Federal Reserve Bank of Boston. 195-221.

De Haan, J. and Sturm, J.E. (1992). The Case for Central Bank Independence, Banca Nazionale del Lavoro Quarterly Review, 45(182), 305-327.

De Kock, M. H. (1974). Central Banking. 4th edition. Staples Press Limited: London.

Economist Intelligence Unit (2015). Democracy Index 2015: Democracy in an age of anxiety. The Economist Intelligence Unit.

Dinchen, N. and Eichengreen, B. (2014). Central Bank Transparency and Independence: Updates and New Measures, International Journal of Central Banking, 10(1), 189-259.

Economist Intelligence Unit (2016). Democracy Index 2016: Revenge of the "deplorables". The Economist Intelligence Unit.

Eijffinger, S. and De Haan, J. (1996). The Political Economy of Central-Bank Independence. Princeton Special Papers in International Economics, No. 19, International Finance Section. Princeton, New Jersey: Princeton University.

Eijffinger, S.and Hoeberichts, M. (2002). Central Bank Accountability and Transparency: Theory and Some Evidence, International Finance, 5(1), 73-96.

Eijffinger, S., Schaling, E., Hoeberichts, M. (1998). Central bank independence: a sensitivity analysis. European Journal of Political Economy, 14(1), 73-88.

Eurobarometer (2017). Retrieved 25-07-2017, from http://ec.europa.eu/commfrontoffice/publicopinion/index.cfm

European Central Bank (2016). Independence, Retrieved 10-06-2017, from https://www.ecb.europa.eu/ecb/orga/independence/html/index.en.html. 
Review of Economic Analysis 11 (2019) 233-254

Fels, J. (2016). The Downside of Central Bank Independence. Pimco Macro Economic Perspectives.

Fischer, S. (2015). Central Bank Independence. Remarks by Stanley Fischer Vice Chairman Board of Governors of the Federal Reserve System at the 2015 Herbert Stein Memorial Lecture National Economists Club Washington, D.C.

Friedman, M. (1962) Should There Be an Independent Monetary Authority?, In B. Y. Leland (ed.), In Search of a Monetary Constitution, Cambridge: Harvard University Press, 219243.

Friseld, L., Roszbach, K. and Spagnolo. G. (2006). Governing the Governors: A Clinical Study of Central Banks. Stockholm: Swedish Riksbank.

Goodman J. (1991). The Politics of Central Bank Independence, Comparative Politics, 23(3), 329-349.

Grilli, V, Masciandaro, D. and Tabellini, G. (1991). Political and Monetary Institutions and Public Financial Policies in the Industrial Countries. Economic Policy, 6(13), 341-392.

Howells, P. and Biefang-Frisancho Mariscal, I. (2006). Monetary policy regimes: A fragile consensus, International Journal of Political Economy, 35(1), 62-83.

Jonsson, G. (1995). Institutions and macroeconomic outcomes - the empirical evidence. Swedish Economic Policy Review, 2, 181-212.

Kaltenthaler, K. Anderson, C. and Miller W. (2010) Accountability and Independent Central Banks: Europeans and Distrust of the European Central Bank, Journal of Common Market Studies, 48(5). 1261-1281.

Kllomp, J. and De Haan, J. (2010) Central bank independence and inflation revisited, Public Choice, 144(3-4), 445-457.

Lastra, R. M. (2006). Legal Foundations of International Monetary Stability. Oxford University Press.

Lybek T. and Morris J. (2004). Central Bank Governance: A Survey of Boards and Management, IMF Working Paper WP/04/226.

Mankiw, G. (2009). Brief Principles of Macroeconomics, 5 Ed, Cengage Learning.

Maxfield, S. (1997). Gatekeepers of Growth: The International Political Economy of Central Banking in Developing Countries, Princeton University Press.

MacLaury; B.K.. (1976). Perspectives on Federal Reserve Independence - A Changing Structure for Changing Times; The Federal Reserve Bank of Minneapolis, Annual Report 1976.

Masciandaro D. and Tabellini G. (1988). Monetary Regimes and Fiscal Deficits: A Comparative Analysis. In H.S. Cheng (ed), Monetary Policy in Pacific Basin Countries. Springer, Dordrecht.

McConnell C. and Brue S. (2008). Macroeconomics: Principles, Problems, and Policies, $17^{\text {th }}$ ed, McGraw-Hill/Irwin. 


\section{KOTSIOS Central Banking in Modern Democracies}

Mishkin F. (2012). Macroeconomics Policy and Practice, Pearson Education.

Moejnak, T. (2014). Central Banking: Theory and Practice in Sustaining Monetary and Financial Stability, Wiley.

Pollard, P. (1993). Central bank independence and economic performance. Federal Reserve Bank of St. Louis Review. 75(4), 21-36.

Price L. (1998). The responsibilities of central banks in the transition economies, Journal of International Development, 10(5). 643-657.

Pringle R. and Mahate A. (1993). The Central Banking Directory. London: Central Banking Publications.

Roach, S. (2007). The great failure of central banking. Fortune Magazine, August 16.

Rossouw, J. and Breytenbach, A. (2011). Identifying central banks with shareholders: A review of available literature. Economic History of Developing Regions. 26(1). 123-130.

Rossouw, J. (2014). Private Shareholding and Public Interest: An Analysis of an Eclectic Group of Central Banks, Economic Research Southern Africa.

Rossouw, J. (2015). Why central banks with shareholders might not be such a bad idea after all, The Conversation, 28-07-2015. Retrieved 20-06-2017, from http://theconversation.com.

Sargent, T. and Wallace, N. (1981). Some Unpleasant Monetarist Arithmetic District Conditions, Federal Reserve Bank of Minneapolis Quarterly Review, 5(3), 1-17.

Sikken, B.J. and Haan, J. (1998). Budget Deficits, Monetization, and Central-Bank Independence in Developing Countries, Oxford Economic Papers, 50(3), 493-511.

Siklos, P. (2012). The Changing Face of Central Banking, Cambridge.

Singleton, J. (2011). Central Banking in the Twentieth Century, Cambridge University Press.

Walsh C. (2002). When should central bankers be fired?, Economics of Governance, 3(1). 121.

Walsh C.. (2005). Central bank independence, Prepared for the New Palgrave Dictionary.

Wood,J. (2015). Central Banking in a Democracy, Routledge.

Wray, R. (2014). Central Bank Independence: Myth and Misunderstanding, Working Paper No. 79, Levy Economics Institute of Bard College. 
Review of Economic Analysis 11 (2019) 233-254

\section{Appendix. Questionnaire replies}

\begin{tabular}{|c|c|c|}
\hline Central Bank & $\begin{array}{l}\text { Dincer- } \\
\text { Eichengreen } \\
\text { indep. index, } \\
2010\end{array}$ & Transparency \\
\hline $\begin{array}{l}\text { Danmarks } \\
\text { Nationalbank }\end{array}$ & $\mathrm{n} / \mathrm{a}$ & Reports, Press releases, Statistics, Speeches, Website, Contact \\
\hline $\begin{array}{l}\text { Swiss National } \\
\text { Bank }\end{array}$ & $\mathrm{n} / \mathrm{a}$ & $\begin{array}{l}\text { Reports, Publications, Press releases, Speeches, Interviews, Bulletins, } \\
\text { Speeches, Contact }\end{array}$ \\
\hline $\begin{array}{l}\text { Reserve Bank of } \\
\text { Australia }\end{array}$ & 0.17 & $\begin{array}{l}\text { Consultation with government, Reports, Presentations to parliament, } \\
\text { Communication program, Media releases, Appearance in committees, Bulletin, } \\
\text { Minutes, Speeches, Website, Contact }\end{array}$ \\
\hline $\begin{array}{l}\text { Oesterreichische } \\
\text { Nationalbank }\end{array}$ & $\mathrm{n} / \mathrm{a}$ & $\begin{array}{l}\text { Reports, Audits, Presentation to Financial Committee, Researches, Forecasts, } \\
\text { Statistics, Website, Contact }\end{array}$ \\
\hline Bank of England & 0.23 & $\begin{array}{l}\text { Reports, Hearings, Minutes, Discussions, Press releases, Statistics, Speeches, } \\
\text { Seminars, Conderences, Website, Contact }\end{array}$ \\
\hline $\begin{array}{l}\text { Banco de } \\
\text { España }\end{array}$ & $\mathrm{n} / \mathrm{a}$ & Reports, Publications, Press Releases, Multimedia, Website, Contact \\
\hline Bank of Japan & 0.35 & $\begin{array}{l}\text { Reports, Publications, Statistics, Minutes, Press Conferences, Speeches, } \\
\text { Website, Contact }\end{array}$ \\
\hline $\begin{array}{l}\text { Federal Reserve } \\
\text { System }\end{array}$ & 0.18 & $\begin{array}{l}\text { Reports, Congress auditions, Minutes, Press releases, Publications, } \\
\text { Conferences, Speeches, , Website, Contact }\end{array}$ \\
\hline Banca d' Italia & $\mathrm{n} / \mathrm{a}$ & $\begin{array}{l}\text { Reports, Parliamentary auditions, Publications, Statistics, Lectures, } \\
\text { Conferences, Speeches, Press releases, Website, Contact }\end{array}$ \\
\hline Latvijas Banka & 0.83 & Reports, Publications, Statistics, Multimedia, Speeches, Website, Contact \\
\hline Bank of Greece & $\mathrm{n} / \mathrm{a}$ & $\begin{array}{l}\text { Reports, Parliament auditions, Publications, Press releases, Statistics, } \\
\text { Speeches, Website, Contact }\end{array}$ \\
\hline Bank Indonesia & 0.73 & Reports, Publications, Press releases, Minutes, Speeches, Website, Contact \\
\hline $\begin{array}{l}\text { Bangko Sentral } \\
\text { ng Pilipinas }\end{array}$ & 0.29 & $\begin{array}{l}\text { Reports, Press releases, Highlights of discussions, Letter to president, } \\
\text { Briefings, Seminars, Conferences, Statistics, Multimedia, Website, Contact }\end{array}$ \\
\hline $\begin{array}{l}\text { Croatian } \\
\text { National Bank }\end{array}$ & 0.73 & $\begin{array}{l}\text { Reports, Publications, Bulletin, Presentations to parliament, Statistics, } \\
\text { Seminars, Minutes, Lectures, Speeches, Conference, Website, Contact }\end{array}$ \\
\hline $\begin{array}{l}\text { Central Bank of } \\
\text { Hungary }\end{array}$ & 0.77 & $\begin{array}{l}\text { Reports, Announcements, Report to minister, Minutes, Statistics, Seminars, } \\
\text { Press releases, Website, Contact }\end{array}$ \\
\hline $\begin{array}{l}\text { National Bank } \\
\text { of Romania }\end{array}$ & 0.79 & $\begin{array}{l}\text { Reports, Press releases, Bulletins, Presentations to parliament, Minutes, } \\
\text { Statistics, Speeches, Website, Contact }\end{array}$ \\
\hline $\begin{array}{l}\text { National Bank } \\
\text { of Serbia }\end{array}$ & $\mathrm{n} / \mathrm{a}$ & $\begin{array}{l}\text { Programme, Reports, Gazette, Press releases, Press conferences, Publications, } \\
\text { Statistics, Social media, Website, Contact }\end{array}$ \\
\hline $\begin{array}{l}\text { Central Bank of } \\
\text { Malaysia }\end{array}$ & 0.49 & $\begin{array}{l}\text { Reports, Publications, Press releases, Speeches, Educational programs, } \\
\text { Multimedia, Website, Contact }\end{array}$ \\
\hline $\begin{array}{l}\text { Hong Kong } \\
\text { Monetary } \\
\text { Authority } \\
\end{array}$ & $\mathrm{n} / \mathrm{a}$ & $\begin{array}{l}\text { Reports, Bulletins, Presentations, Meetings, Statistics, Seminars, Minutes, } \\
\text { Speeches, Website, Contact }\end{array}$ \\
\hline
\end{tabular}

